\title{
Influence of soil temperature and water content on fine-root seasonal growth of European beech natural forest in Southern Alps, Italy
}

\author{
A. Montagnoli $\cdot$ A. Di Iorio $\cdot$ M. Terzaghi $\cdot$ \\ D. Trupiano $\cdot$ G. S. Scippa $\cdot$ D. Chiatante
}

Received: 22 January 2014/Revised: 7 April 2014/Accepted: 25 April 2014/Published online: 11 May 2014

(C) Springer-Verlag Berlin Heidelberg 2014

\begin{abstract}
In tree species, fine-root growth is influenced by the interaction between environmental factors such as soil temperature (ST) and soil moisture. Evidences suggest that if soil moisture and nutrient availability are adequate, rates of root growth increase with increasing soil temperature up to an optimum and then decline at supraoptimal temperatures. These optimal conditions vary between different taxa, the native environment and the fine-root diameter sub-classes considered. We investigated the effects of seasonal changes of both ST and soil water content (SWC) on very fine $(d<0.5 \mathrm{~mm})$ and fine-root $(0.5<d<2 \mathrm{~mm})$ mass (vFRM, FRM) and length (vFRL, FRL) in Italian Southern Alps beech forests (Fagus sylvatica L.). Root samples were collected by soil core method. Turnover rate was higher for the very fine $(0.51)$ than for the fine (0.36) roots. vFRM, FRM, vFRL and FRL displayed a complex seasonal pattern peaking in summer when SWC was around $40 \%$ and ST was around $14{ }^{\circ} \mathrm{C}$. Above this temperature, under almost constant SWC, all above mentioned root traits decreased. vFRM, FRM, vFRL and FRL showed significant second-order polynomial relationship $(p<0.05)$ with SWC for both diameter classes, with the only exception of SRL. ST showed the same kind of relationship significant only with vFRM and vFRL, the latter within the $12-16{ }^{\circ} \mathrm{C}$ smaller range. Interpolation
\end{abstract}

Communicated by R. Matyssek.

A. Montagnoli $(\bowtie) \cdot$ A. Di Iorio - M. Terzaghi - D. Chiatante Department of Biotechnology and Life Science, University of Insubria, Varese, Italy

e-mail: antonio.montagnoli@uninsubria.it

D. Trupiano - G. S. Scippa

Department of Science and Technology for Environment and

Territory, University of Molise, Pesche, IS, Italy analysis between root mass and length for both diameter classes and investigated soil environmental characteristics (ST and SWC) showed a clear roundish delineation only for vFRM. In conclusion, these findings clarified the occurrence of a bimodal fine-root growth seasonal pattern for our beech forest. The optimal growth ST and SWC ranges were delineated only for very fine roots, giving further evidence on this root category as the more responsiveness to soil environmental changes. Furthermore, $F$. sylvatica seems to adopt an intensive strategy to cope with decreasing SWC. Finally, fine-root growth, mainly radial type, seems to be driven by SWC, whereas very fine-root growth, mainly longitudinal type, seems to be driven by ST.

Keywords Fagus sylvatica $\cdot$ Fine-root growth $\cdot$ Fine-root diameter · Fine-root production · Turnover rate $\cdot$ Soil temperature $\cdot$ Soil water content $\cdot$ Synoptic analysis

\section{Introduction}

In forest ecosystems, the belowground biomass accounts for $13-25 \%$ of the stand biomass, 2-15\% consisting of fine roots (Helmisaari et al. 2002). A substantial fraction of net primary productivity in forested ecosystems is exported belowground to produce ephemeral fine roots. Despite their relatively minor contribution to the overall root biomass (Vogt et al. 1996), fine-root turnover represents up to $33 \%$ of the total annual net primary production in most ecosystems (McClaugherty et al. 1982). Therefore, fine-root dynamics is widely recognized as an important biogeochemical process in forest soils.

Within a root system, very fine $(d<0.5 \mathrm{~mm})$ and fine $(0.5<d<2 \mathrm{~mm}$ ) roots (nomenclature according to Zobel 
and Waisel 2010) represent the most dynamic component of a root apparatus (Hendrick and Pregitzer 1992; Barlow 2010). Given their simple anatomical organization, fine roots are also the most sensitive component within the overall root system in that they respond rapidly to variations in the rooting environment (Helmisaari et al. 2002). In previous studies on Turkey oak, we showed that fineroot responses to changes in soil water content (SWC) are diameter dependent (Montagnoli et al. 2012a). Joslin et al. (2006) hypothesized that a tree fine-root system consists of two pools, one very dynamic with lifespan $<1$ year (shortlived), the other with lifespan $>1$ year (long-lived). Moreover, Gill and Jackson (2000) highlighted how differences in lifespan correspond to differences in fine-root diameter size, with decreasing turnover rates as root diameter increases. Hence, irrespective of tree species, it is increasingly recognized that woody fine roots $(0.5-2 \mathrm{~mm})$ represent the more stable pool in fine-root systems, whereas very fine roots $(<0.5 \mathrm{~mm})$ the more dynamic one.

Fine-root dynamics is influenced by a variety of internal (e.g. genotype of plant species) and external (e.g. temperature, precipitation, soil properties, nutrient availability and competition between plants) factors (Teskey and Hinckley 1981, Kuhns et al. 1985, Burke and Raynal 1994, Steele et al. 1997, Tierney et al. 2003, Chiatante et al. 2005, Majdi et al. 2005, Montagnoli et al. 2012a). In particular, soil temperature (ST) influences root growth (Pregitzer et al. 2000), including the initiation and cessation of growth, cell elongation, root length and diameter extension, initiation of new lateral roots, and by these regulates other vital functions of a tree (Lyr and Garbe1995; Lyr 1996). Roots grow faster at higher temperatures in annual crop plants (Kaspar and Bland 1992) and perennials (Larson 1970; Wilcox and Ganmore-Neumann 1975; Teskey and Hinckley 1981; Bevington and Castle 1985; Kuhns et al. 1985; Lieffers and Rothwell 1986; McMichael and Burke 1998; King et al. 1999; Weltzin et al. 2000). Rates of root mortality also seem to increase with ST and the flux of C from plant roots into the soil food web might increase in global temperatures rise as predicted (Pregitzer et al. 2000 and reference therein). Certainly changes in ST interact with changes in both soil moisture and nutrient availability (Pregitzer et al. 2000) driving changes in root growth. Therefore, responses of roots to changes in ST have the potential to be confounded by root responses to concomitant changes in both soil nutrient and water availability. Considerable evidences suggest that if soil moisture and nutrient availability are adequate, rates of root growth increase with increasing ST, up to an optimal temperature and then decline at supraoptimal temperatures (Barney 1951; Merrit 1968; McMichael and Burke 1998; Pregitzer et al. 2000). All these findings are not sufficient to explain the field performance observed throughout the growing season by the fine root. Joslin et al. 2001 suggested that in a temperate climate with a mid-summer drought period, mature deciduous trees exhibit a 'fixed root growth' pattern attributable primarily to 'phenological programming' and secondly to 'physiological optimum' of ST and soil water potential. The physiological optimum, defined as the growth rate at the point of most advantageous balance between rate limiting conditions (Lyr and Hoffmann 1967), depends partly on the native environment and varies among different taxa (Pregitzer et al. 2000; Larson 1970; Tryon and Chapin 1983; McMichael and Burke 1998; Comas et al. 2002; Curt and Prevosto 2003; Comas and Eissenstat 2004). Synoptic analysis, widely used in GIS environment (Piovesan et al. 2005), could be suitable for the investigated soil characteristics (ST and SWC) delineation in relation to optimal root growth. This approach provides especial visualization procedure which gives the most informative results (Čermák et al. 2004). Therefore, we hypothesize that if ST and water content physiological optimum occurs, then fine-root growth response should be delineated in a 2D more instructive fashion shape easy to visualize.

Soil resources are subject to fluctuation in time and/or space influencing the species' activity and fate. Therefore, in temperate forests, perennial plants exhibit complex seasonal patterns of root production and root mortality, all characterized by marked spring burst production and fall mortality (Kuhns et al. 1985; Hendrick and Pregitzer 1993, 1996; Wells and Eissenstat 2001; Metcalfe et al. 2008; Montagnoli et al. 2012a, b; Montagnoli et al. 2010). In northern forest where water limitation is rare, ST is the main determinant for fine-root growth which increases from spring to mid-summer and declines in fall when most of root mortality occurs (Brassard et al. 2009; Tierney McClaugherty et al. 1982; Kurz and Kimmins 1987; Hendrick and Pregitzer 1992, 1993, 1996). Differently, in temperate forest with summer water limitation, plants have different species-specific adaptation strategies termed stress-tolerance or stress-avoidance, by exhibiting fine-root mass and length increase (Montagnoli et al. 2012a; Ostonen et al. 2007, 2011; Di Iorio et al. 2011) or decrease (Manes et al. 2006; Metcalfe et al. 2008), respectively, as soil moisture declines.

Plants optimize the investment of carbon by modifying their fine-root morphology (Montagnoli et al. 2012a). Increasing specific root length (SRL m g ${ }^{-1}$ ), i.e. the lengthto-mass ratio of a root fragment, is one of the possible fineroot morphological adaptation (intensive strategy), which increases the volume of soil exploited per unit biomass invested in fine roots. In fact, root length is assumed to be proportional to resource acquisition (benefit) and root mass to be proportional to construction and maintenance (cost) (Fitter 1976, 1985, 1991; Eissenstat and Yanai 1997). Long 
and thin roots (high SRL) are believed to be the belowground equivalent of thin leaves, which are less expensive to produce (Withington et al. 2006; Ostonen et al. 2007). Water uptake may stimulate the production of finer roots, which results in a relatively greater length per unit mass, thereby leading to an increase in SRL under drier conditions (Metcalfe et al. 2008). Thus, a decline in soil moisture and/or an increase in ST in some species may induce changes in the diameter of fine-root system (Ostonen et al. 2007). However, different tree species appear to have different adaptation strategies for optimizing the mineral nutrition of the plant (Comas et al. 2002; Curt and Prevosto 2003; Comas and Eissenstat 2004).

The research presented here was part of a larger study designed to evaluate different aspect of both fine (Montagnoli et al. 2012a, b; Terzaghi et al. 2013) and coarse (Di Iorio et al. 2013) roots in beech forest in relation to stand characteristics. In the present paper, our objectives were to evaluate (1) the seasonal variation of live fine-root mass, length and SRL; (2) the relationship, if any, between volumetric soil moisture and temperature and live fine-root mass, length and SRL; (3) the fine-root production and turnover rate; (4) how the aforementioned fine-root traits vary in relation to two fine-root diameter classes $(<0.5$; $0.5-2 \mathrm{~mm}$ ); and (5) the occurrence, by data interpolation, of a 2D colour visualization of SWC and ST optimum for both fine and very fine-root growth.

\section{Materials and methods}

Site description and characteristics

The study area is located in the catchments of the Telo stream in the Lombardy Southern Alps (Intelvi Valley, NW Italy, $\left.45^{\circ} 59^{\prime} \mathrm{N}, 9^{\circ} 07^{\prime} \mathrm{E}\right)$ approximately from 1,160 to 1,200 $\mathrm{m}$ above sea level between Lakes Como and Lugano. This area is characterized by a sub-continental climate with mean annual precipitation of $1,600 \mathrm{~mm}$ concentrated in two main periods (April-May and August-September), and mean annual temperature of $10-11{ }^{\circ} \mathrm{C}$ (Fig. 1; data from Consorzio dell'Adda 2003-2008 San Fedele Intelvi). Rainfall $(\mathrm{mm})$ and air temperature $\left({ }^{\circ} \mathrm{C}\right)$ for the sampling period were recorded at $60 \mathrm{~min}$ interval. Sensors (Thermometer DMA572 and Rain gauge DQA030; LSI Lastem s.r.l.) were mounted on a 3-m-high mast and set up on a hill (Alpe di Ponna) $0.8 \mathrm{~km}$ from the experimental site. Generally, the area is snow-covered from late October to late March. The 2008 temperatures and precipitations are in accordance with the general trend and magnitude of the past 80 years (weather data from Consorzio dell'Adda, Lombardy, 1920-2000). According to the World Reference Base (WRB) for soil resources (IUSS 2006), soil type is
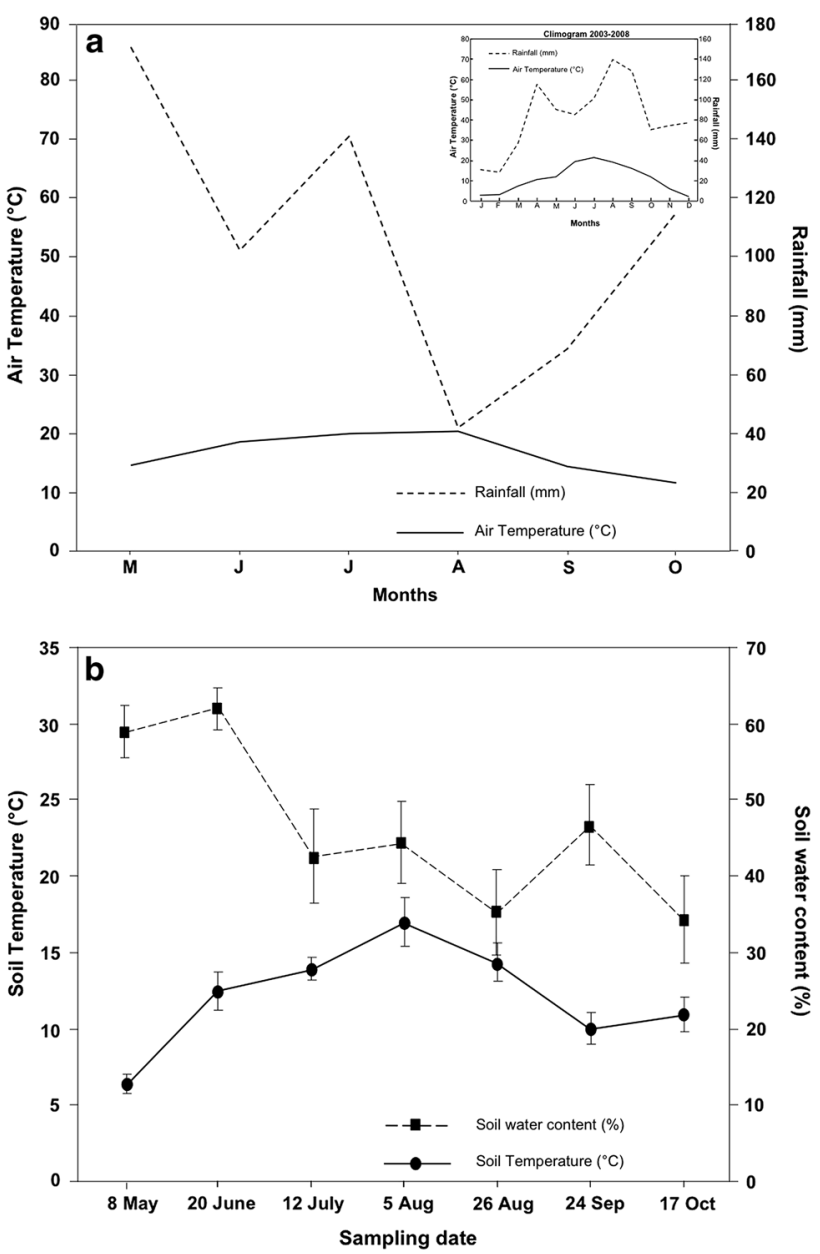

Fig. 1 Inner panel a Monthly average air temperature (solid line) and rainfall (broken line) from January to December for the period 2003-2008 (data from Consorzio dell'Adda); a monthly average air temperature (solid line) and rainfall (broken line) during the 2008 experimental period. b Seasonal variation of soil water content (filled square) and temperature (filled circle) at each sampling date. Data are means $\pm 1 \mathrm{SD}$

Leptosol $40-50 \mathrm{~cm}$ deep. Sampling plots were placed in three beech forest stands, with different characteristics due to different type and age of forest management (Table 1). In particular, stands were one 40-year-old Coppice and two conversions from coppice to high forest, respectively, cut in 1994 and 2004. Effects of these management practices on fine-root production and turnover rate were exhaustively investigated in previous works (Montagnoli et al. 2012b; Terzaghi et al. 2013; Di Iorio et al. 2013). As soil conditions appeared to be inherently coupled with stand characteristics, present fine-root biomass data from three selected stands were pooled in order to detect a comprehensive response to ST and water content. The three stands were adjacent to each other and located on the same southwest facing slope (angle average between $28^{\circ}$ and $30^{\circ}$ ). No significant differences in soil characteristics were recorded 
Table 1 Tree characteristics for the three stands

\begin{tabular}{lllccc}
\hline Stand & Management type & Tree density (trees ha $\left.{ }^{-1}\right)$ & Tree dbh $(\mathrm{cm})$ & Tree height (m) & $\begin{array}{c}\text { Aboveground biomass } \\
\left(\mathrm{Mg} \mathrm{ha}^{-1}\right)\end{array}$ \\
\hline 1 & Coppice & $724 \pm 35$ & $17.2 \pm 0.7$ & $12.1 \pm 0.3$ & $248.5 \pm 15.6$ \\
2 & Conversion (1994) & $279 \pm 24$ & $22.6 \pm 1.5$ & $12.8 \pm 0.7$ & $123.7 \pm 7.3$ \\
3 & Conversion (2004) & $167 \pm 20$ & $31.9 \pm 1.9$ & $18.9 \pm 0.8$ & $91.8 \pm 20.2$ \\
\hline
\end{tabular}

Data shown are the mean and standard error (SE). Aboveground biomass values are the mean of seven replicates

$d b h$ diameter at breast height

between the three stands. Tree number and diameter at breast heights (dbh) were surveyed on seven selected 20-mdiameter circular-shaped sampling plots per stand (a total of $2,199 \mathrm{~m}^{2}$ per stand). In order to estimate aboveground biomass, a site specific allometric relationship, which estimates branch and stem biomass from tree dbh, was developed. More detailed information about stand characteristics were provided in Montagnoli et al. (2012b), Di Iorio et al. (2013) and Terzaghi et al. (2013).

\section{Soil moisture and temperature}

ThetaProbe type ML2 Delta-T Devices were used to record the volumetric soil water content (SWC; \%) by the wellestablished method of responding to changes in the apparent dielectric constant. Measurements of soil temperature $\left(\mathrm{ST} ;{ }^{\circ} \mathrm{C}\right)$ were taken by Checktemp 1 thermometer with an NTC thermistor sensor (Hanna Instruments ${ }^{\circledR}$ ) $\left( \pm 0.3{ }^{\circ} \mathrm{C}\right)$. Both soil moisture and ST were measured at each sampling date, approximately every 30 days from 8 May to 17 October. Proximal to the root soil core sampling point, 12 measurements each of ST and SWC were taken at each of the three soil depths $(5,15$ and $25 ; 36$ in total) hereafter reported as mean $30 \mathrm{~cm}$ depth.

\section{Fine-root measurements}

Fine roots were collected using a motor-driven portable root soil core sampler [adapted from Ponder and Alley (1997)] during the 2008 growing season from May to October 2008, when the soil was free of snow. In each stand, four permanent $10-\mathrm{m}^{2}$ plots were set. Two soil cores $(4 \mathrm{~cm}$ diameter $\times 30 \mathrm{~cm}$ deep) were randomly collected in each plot. Fine roots were sampled on seven dates approximately every 30 days from 8 May to 17 October for 168 cores in total $(8$ cores $\times 3$ stands $\times 7$ collecting dates). Samples were stored in plastic bags at $4{ }^{\circ} \mathrm{C}$ until processed. Each sample was washed automatically in a filtering nylon bag $(300-\mu \mathrm{m}$ mesh) using a washing machine [adapted from Benjamin and Nielsen (2004)]. Soil-free roots were sorted into colour, texture and shape under a 10× stereomicroscope (Vogt and Persson 1991). Live fine roots were scanned at resolution of $400 \mathrm{dpi}$ and divided into subsamples based on two diameter size classes $(d<0.5 \mathrm{~mm}$ hereafter named very fine roots; $0.5<d<2.0 \mathrm{~mm}$ hereafter named fine roots) by using WinRhizo Pro V. 2007d (Regent Instruments Inc., Quebec). Each subsample class was analysed in order to obtain the mean diameter class. Subsamples were then oven-dried and weighed.

As the present work is strictly focused on the growing season, annual fine-root production (FRP) and fine-root turnover rates (FRT) estimations were calculated on this temporal basis. The reliability of this estimation relies on the lack of significant differences between the fall and the second season spring values as reported in a previous work (Montagnoli et al. 2012b). Annual fine-root production was estimated using the minimum-maximum method procedure. This method calculates, and sums in case of multimodal seasonal pattern, only significant differences between seasonal minimum and maximum fine-root dry mass (live mass plus necromass) (Edwards and Harris 1977; McClaugherty et al. 1982; Hertel and Leuschner 2002). Fine-root turnover rates of FRB (live mass) were calculated as annual root production divided by maximum standing biomass (Gill and Jackson 2000; Godbold et al. 2003). In a recent review on different types of fine-root turnover calculations, Brunner et al. (2013) highlighted how maximum rather than mean annual biomass is more susceptible to fluctuations due to climatic variation. Therefore, in accordance with the aims of the present study, the 'maximum method' was considered more consistent.

The following root traits were determined: (1) mean live dry mass of very fine root ( $\left.\mathrm{vFRM}-\mathrm{g} \mathrm{m}^{-2}\right)$ and fine root $\left(\right.$ FRM $\left.-\mathrm{g} \mathrm{m}^{-2}\right)$; (2) mean live length (RL) of very fine root $\left(\mathrm{vFRL}-\mathrm{m} \mathrm{m}^{-2}\right)$ and fine root $\left(\mathrm{FRL}-\mathrm{m} \mathrm{m}^{-2}\right)$; (3) specific root length (SRL) of very fine root ( $\mathrm{vF}$ SRL $-\mathrm{m} \mathrm{g}^{-1}$ ) and fine root $\left(\mathrm{F} \mathrm{SRL}-\mathrm{m} \mathrm{g}^{-1}\right)$; (4) seasonal pattern of the above mentioned traits; (5) turnover rate of very fine root (vFRT) and fine root (FRT).

Statistical analysis

Twelve permanent plots (four per stand) were established and considered as replicates. At each sampling date, two soil cores per plot were sampled, pooled and treated as one 
Table 2 Root dry mass, length, SRL, production and turnover rate for two fine-root diameter classes

\begin{tabular}{|c|c|c|c|c|c|c|c|}
\hline \multirow[t]{2}{*}{ Diameter class (mm) } & \multicolumn{2}{|l|}{ Dry mass } & \multicolumn{2}{|l|}{ Length } & \multirow{2}{*}{$\begin{array}{l}\mathrm{SRL}^{\mathrm{a}} \\
\left(\mathrm{m} \mathrm{g}^{-1}\right)\end{array}$} & \multirow{2}{*}{$\begin{array}{l}\mathrm{RP}^{\mathrm{b}} \\
\left(\mathrm{g} \mathrm{m}^{-2} \mathrm{y}^{-1}\right)\end{array}$} & \multirow{2}{*}{$\begin{array}{l}\mathrm{RT}^{\mathrm{c}} \\
\left(\mathrm{y}^{-1}\right)\end{array}$} \\
\hline & $\left(\mathrm{g} \mathrm{m}^{-2}\right)$ & $\overline{\%}$ & $\left(\mathrm{~m} \mathrm{~m}^{-2}\right)$ & $\%$ & & & \\
\hline $\mathrm{vF}^{\mathrm{d}}(0-0.5)$ & $37.8 \pm 1.7$ & 24 & $1,536.5 \pm 69.4$ & 83 & $41.3 \pm 0.7$ & 29.32 & 0.51 \\
\hline $\mathrm{F}^{\mathrm{e}}(0.5-2)$ & $122.5 \pm 6.2$ & 76 & $327.2 \pm 15.3$ & 17 & $2.9 \pm 0.05$ & 55.34 & 0.36 \\
\hline
\end{tabular}

${ }^{a} S R L$ specific root length

${ }^{\mathrm{b}} R P$ root annual production

c $R T$ root turnover rate

d $v F$ very fine root

${ }^{\text {e }} F$ fine root

$(n=12)$. To test the significance of each peak in the seasonal pattern, the Dunnett's test (unilateral alternative, $p<0.05$ ) was applied to differences among the peak (reference mean) and both prior and subsequent first minimum values (Montagnoli et al. 2012a, b). Mann-Whitney two samples test was used for FRP estimation (i.e. difference between maximum and minimum). Linear or nonlinear regression analyses were performed to model the effect of soil moisture and temperature on both very fine- and fine-root length, mass and SRL. Statistical analyses were carried out with SPSS 17.0 (SPSS Inc, Chicago IL, USA). Synoptic analysis based on relationship maps between root mass or root length and investigated soil traits (ST and SWC) was performed with OriginPro 8 SR0 (OriginLab Corporation, USA). This approach relies on data interpolation which delineates $x y$ variables (SWC and ST, respectively) ranges with equal $z$-response values (root mass or length).

\section{Results}

Soil moisture and temperature

As a result of spring rainfall events (Fig. 1a), the highest SWC was recorded from 8 May (59 \%) to 20 June $(61.7 \%$; Fig. 1b). Then, SWC progressively decreased from $42.5 \%$ on 12 July to almost $35 \%$ on 26 August. SWC increased again to $46 \%$ on 24 September as a result of early autumn rainfall, for decreasing to $34 \%$ at the last sampling date on 17 October. ST was in average lower than air temperature of $3-5{ }^{\circ} \mathrm{C}$. Both soil and air temperatures showed the same seasonal variation increasing from 8 May to 5 August and then decreasing till the middle of October with the only exception of a slight increase in the soil at the end of the growing season (Fig. 1a, b).

Fine-root production and turnover

Table 2 shows root production and turnover rate values calculated with respect to the selected diameter classes.
Annual root production was lower in very fine $(<0.5 \mathrm{~mm})$ than fine roots $(0.5-2 \mathrm{~mm})$, the former accounting for almost $29 \%$ of the total $(d<2 \mathrm{~mm})$. On the contrary, root turnover rate in the smaller diameter class was higher than twice that in the larger class.

Root dry mass, length and SRL

Mean annual standing mass was almost four times higher in FRM than vFRM, accounting for 76 and $24 \%$ of the total, respectively. In contrast, vFRL was $83 \%$ of total root length (Table 2). In both diameter classes, both root mass and length showed two distinct peaks during the growing season on 12 July and 24 September (Fig. 2), of which only the first statistically significant (Dunnett's test, $p<0.05$ ). In particular, from the beginning of the season to the seasonal maximum, both vFRM and vFRL doubled their values whereas the larger roots only increased by $50 \%$. Both peaks occurred when ST was lower than its seasonal maximum and SWC ranged between $42 \%$ (first) and $46 \%$ (second) (Fig. 1b).

High seasonal variation of SRL occurred for both diameter classes with two distinct peaks (Fig. 2). In the case of $\mathrm{vF}$ SRL, both peaks were coincident with those observed for the mass and the length as well as the first peak of F SRL. None of the peaks were statistically significant, with the only exception of the second one for $\mathrm{F}$ SRL (Dunnett's test, $p<0.05$ ) in the end of August, anticipating by 29 days that of $\mathrm{vF}$ SRL. This peak corresponded to the second seasonal minimum for both FRM and FRL, with FRM markedly lower than FRL compared to the other sampling dates.

Root mass showed a significant $(p<0.05)$ secondorder polynomial relationship with the soil moisture for both diameter classes considered, whereas root length with only the fine-root class (Fig. 3). The coefficient of determination $\left(\mathrm{R}^{2}\right)$ did not show great variation between diameter classes or between root mass and length. A second-order polynomial relationship significantly occurred also between vFRM and ST ( $p<0.05$; Fig. 4$)$. For vFRL, 

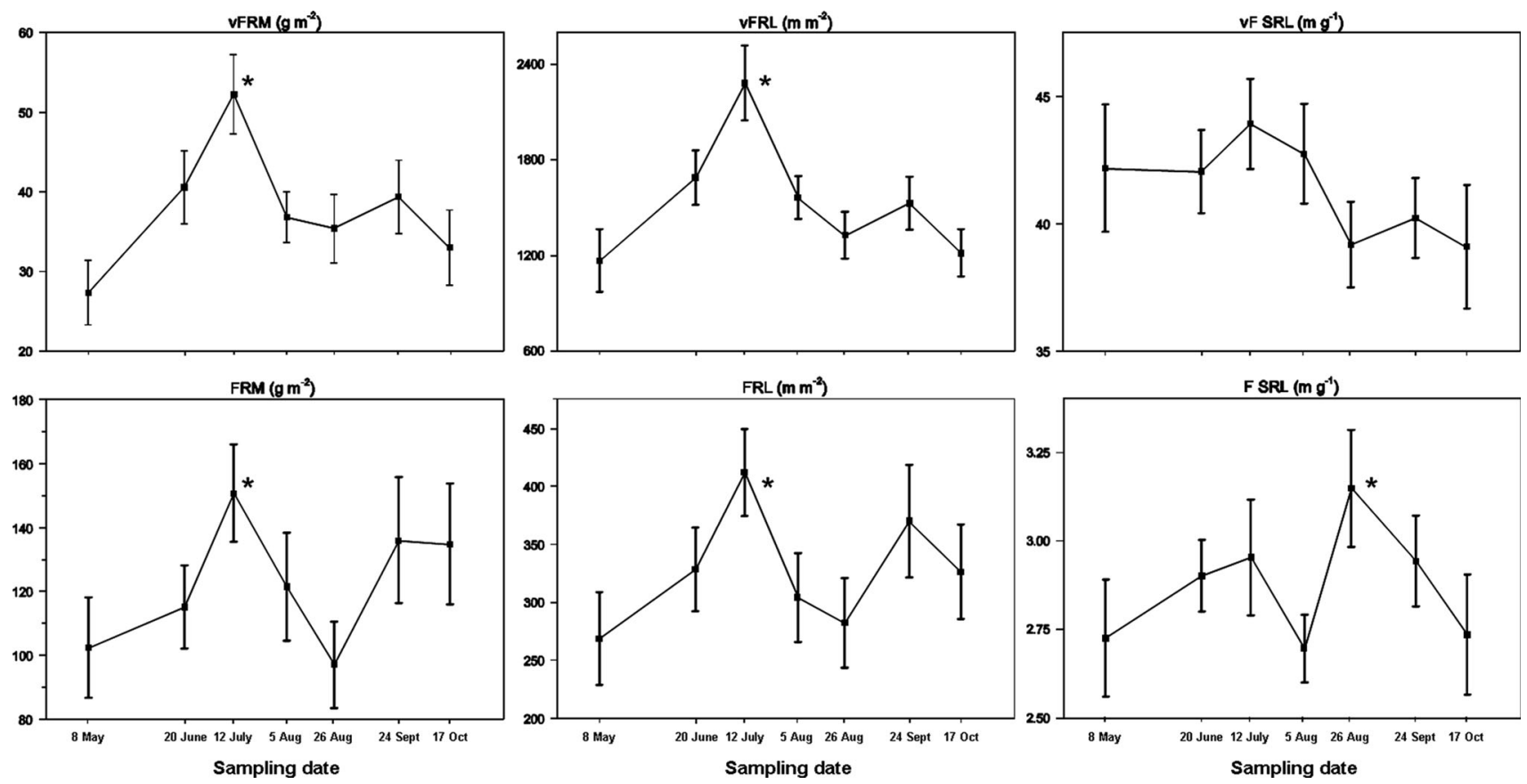

Fig. 2 Seasonal patterns of root mass (RM), length (RL) and specific root length (SRL) (columns) according to diameter classes ( $\mathrm{vF}$ and F; rows). Data refer to each sampling date represented as means

$(n=12) \pm 1$ SE. Asterisks indicate statistically significant peaks (Dunnett's test, $p<0.05$ )
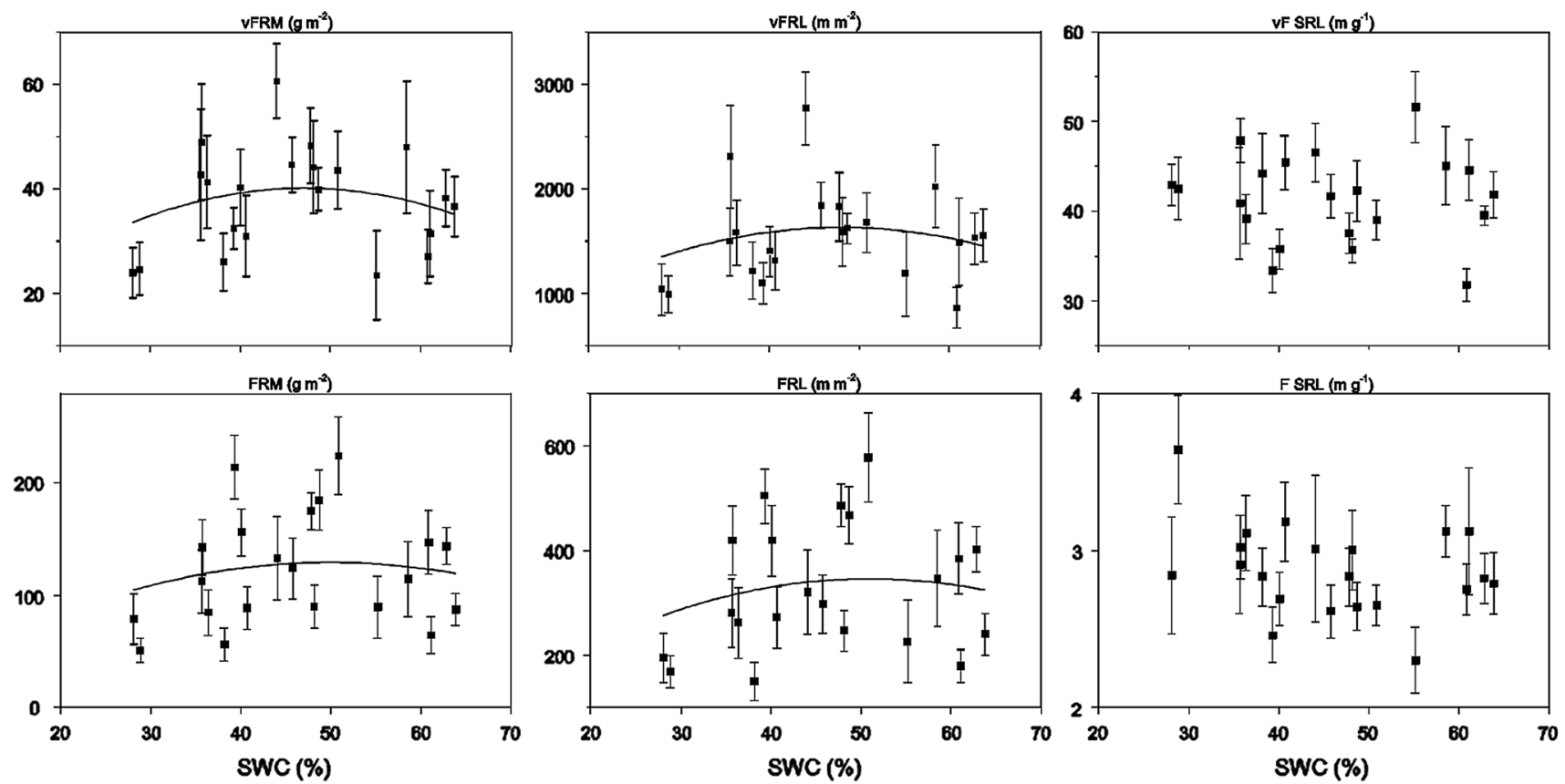

Fig. 3 Relationship between volumetric soil moisture (SWC) and root mass (RB), length (RL) and specific root length (SRL) (columns) according to diameter classes ( $\mathrm{vF}$ and $\mathrm{F}$; rows). Each point is the

mean of 7 sampling dates (May-October 2008) per stand. If present, the second-order polynomial is significant at $p<0.05$

the relationship was not significant over the whole investigated temperature range. Starting from the evident maximum vFRL value at $14.03{ }^{\circ} \mathrm{C}$, progressively shorter ranges were selected till the second-order polynomial

relationship met the significance $(p<0.05), 12-16{ }^{\circ} \mathrm{C}$ range exactly (Fig. 4). For both diameter classes, SRL did not show significant relationship neither with soil moisture (Fig. 3) nor with ST (Fig. 4). 

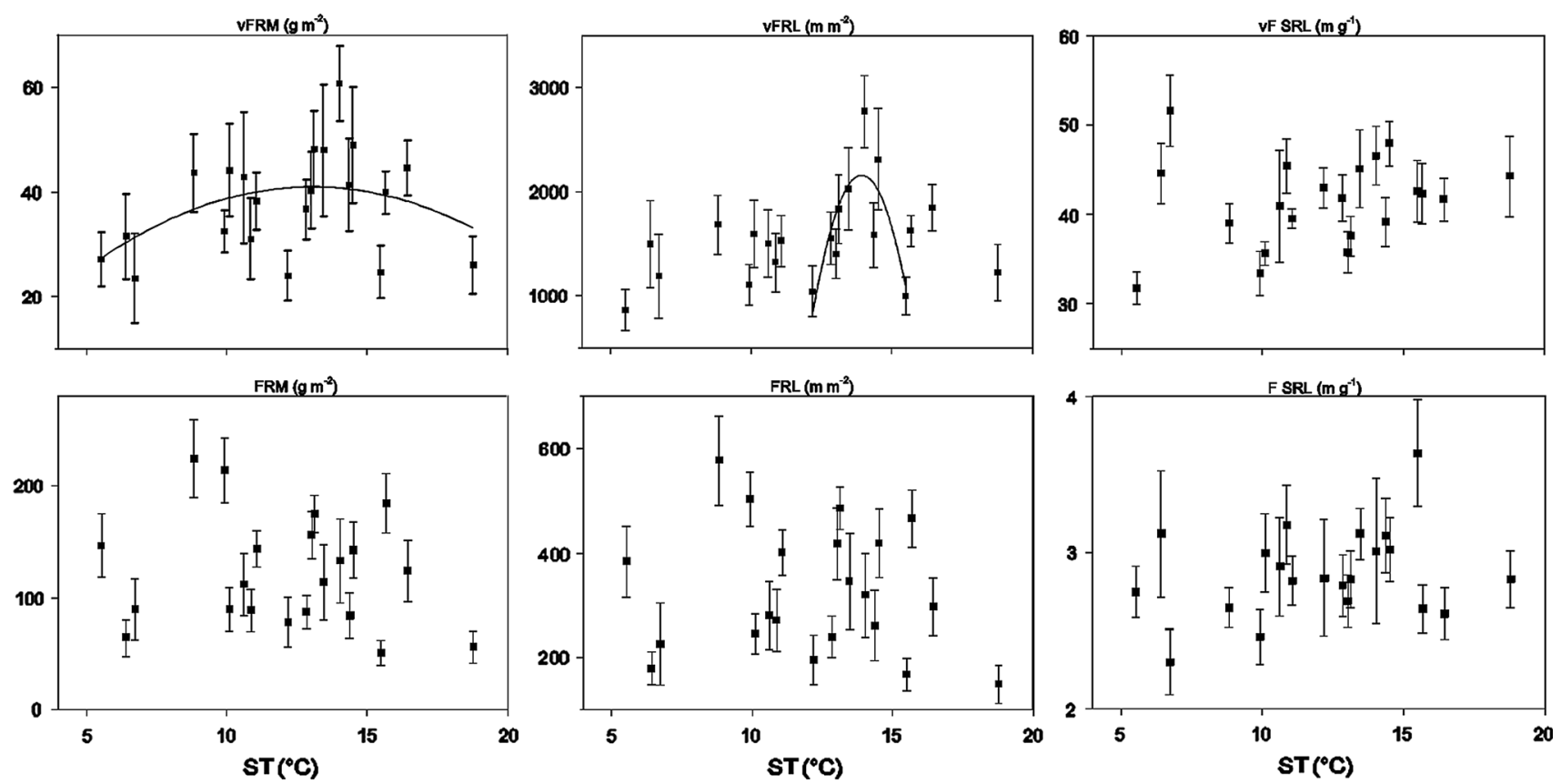

Fig. 4 Relationship between soil temperature (ST) and root mass (RM), length (FRL) and specific root length (SRL) (columns) according to diameter class ( $\mathrm{vF}$ and $\mathrm{F}$; rows). Each point is the mean

of 7 sampling dates (May-October 2008) per stand. If present, the second-order polynomial is significant at $p<0.05$. For vFRL, the regression fitted within $12-16{ }^{\circ} \mathrm{C}$ soil temperature range

Synoptic analysis of root mass, ST and water content

Synoptic analysis was carried out only for those root parameters which showed a significant polynomial relationship with at least one of the two soil environmental parameters investigated, temperature and water content. Consequently, due to their lack of relationship, vF SRL and F SRL were excluded. Contour plot graphs (Fig. 5) representing the seasonal variation of RM and RL (multiple colour) showed that a clear roundish (2D view) delineation occurred only if root parameters showed a significant polynomial relationship with both SWC and temperature. In particular, this was the case only for vFRM and vFRL. Maximum values of vFRM and vFRL in the upper $30-\mathrm{cm}$ soil depth corresponded to $42-46 \%$ SWC range and to $14-15{ }^{\circ} \mathrm{C}$ ST range. For FRM and FRL, as the significant polynomial relationship was found only with SWC (Fig. 4), interpolation analysis did not result in a clear delineation of contour plot. In particular, maximum value for both FRM and FRL was located in the lower range of ST and covered a wide range of SWC.

\section{Discussion}

In our beech stands in the Southern Alps of Italy, the mean total live fine-root mass $\left(160 \mathrm{~g} \mathrm{~m}^{-2}\right)$ was consistent with other values reported for the same species (Finér et al.

2007) and for the temperate deciduous forests (Finér et al. 2011), falling in the lower limit of these reference ranges. The large variation of fine-root biomass observed between sites of the same vegetation zone may partly originate from differences in sampling methods (Vogt et al. 1998), climatic and stand characteristics (Finér et al. 2007, 2011; Gill and Jackson 2000). Our field estimations of fine-root length $\left(1.85 \mathrm{~km} \mathrm{~m}^{-2}\right)$, frequently missing in literature, was almost half than that reported for temperate deciduous forest biome $\left(5.4 \mathrm{~km} \mathrm{~m}^{-2}\right.$ to $30 \mathrm{~cm}$ soil depth) (Jackson et al. 1997), but very close to the value $\left(1.5 \mathrm{~km} \mathrm{~m}^{-2}\right)$ recently found for mixed beech forest (Bolte and Villanueva 2006). In a recent meta-analysis on different tree species, Ostonen et al. (2007) reported fine-root SRL values widely ranging between 1.4 and $25 \mathrm{~m} \mathrm{~g}^{-1}$. Moreover, the same authors reported also SRL estimations for Fagus sylvatica, scaled down to smaller diameter sub-classes. Our results for both root class $<2 \mathrm{~mm}$ in diameter $\left(11.6 \mathrm{~m} \mathrm{~g}^{-1}\right)$ and the two diameter sub-classes considered in this study $\left[d<0.5\left(41.3 \mathrm{~m} \mathrm{~g}^{-1}\right)\right.$ and $\left.0.5<d<2\left(2.9 \mathrm{~m} \mathrm{~g}^{-1}\right)\right]$ fall within this meta-analysis's range. Finally, annual FRP and turnover rate values fall within the range reported for temperate deciduous forests (Finér et al. 2011) and are consistent with data obtained in a previous work on the same site (Montagnoli et al. 2012a).

Although referred to one growing season, the observed turnover rates highlight turnover times of 2 and 3 years for very fine and fine roots, respectively. Consequently, we 

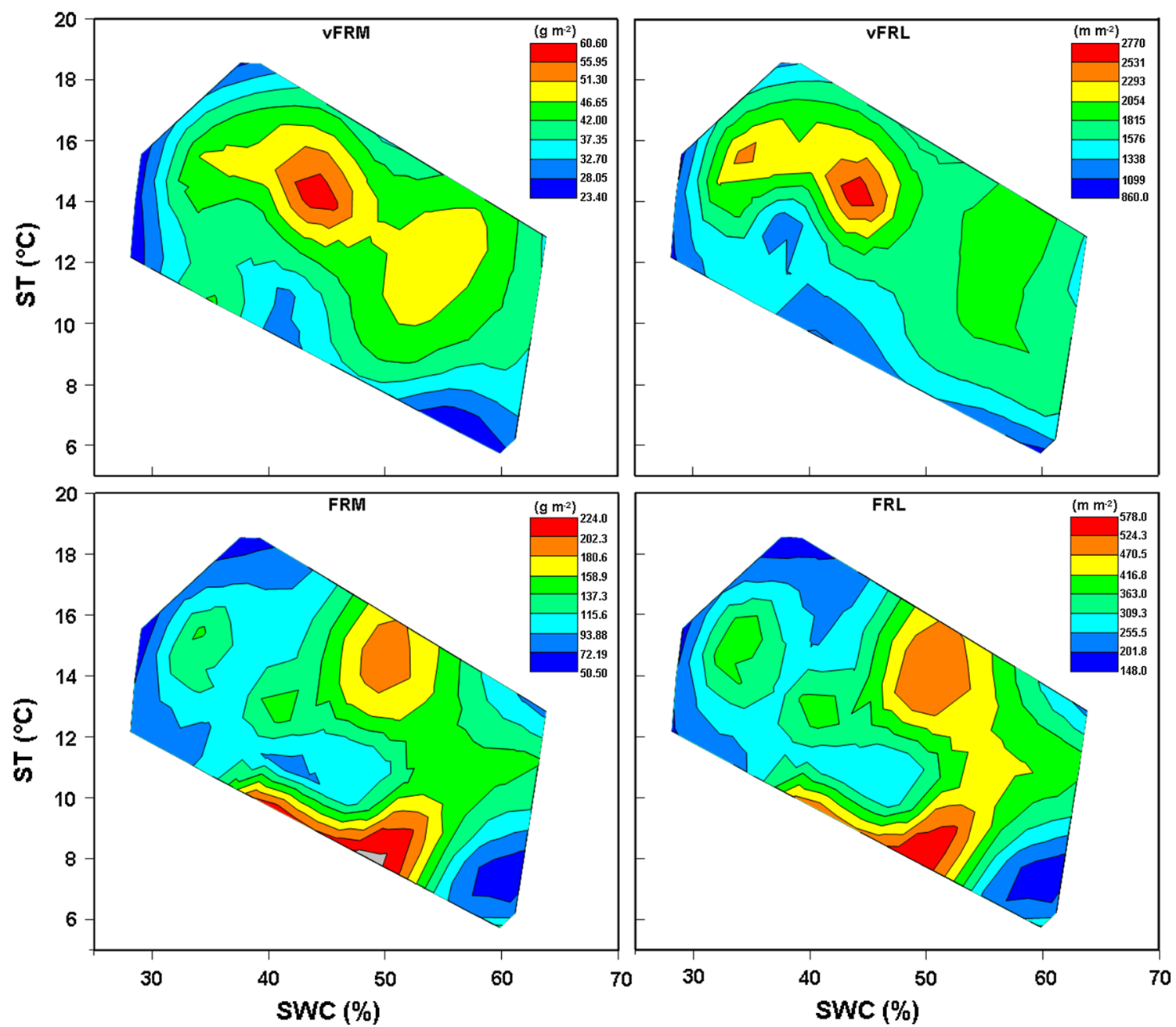

Fig. 5 2D colour visualization representing very fine-root mass $(\mathrm{vFRM})$ and very fine-root length (vFRL; $\mathrm{d}<0.5 \mathrm{~mm}$ ) (upper panels), fine-root mass (FRM) and fine-root length (FRL; $0.5<\mathrm{d}<2$ ) (lower panels), in relation to soil temperature (ST)

infer that another root portion accounting for $\approx 50$ and $\approx 30 \%$ for very fine and fine roots, respectively, has a turnover time shorter than one growing season. In our study, seasonal pattern's peak of very fine and fine roots measured in July lasted only few weeks, suggesting that most of the new produced fine roots are 'short-lived' type. Furthermore, though less pronounced than the previous one, also the second flush measured in September lasted few weeks pointing out the production of a second 'shortlived' fine roots population. If this is the case, the amount of very fine and fine roots surviving the winter time and those at the beginning of the growing season (spring) might represent the 'long-lived' fine-root portion of the root system. Similarly to previous works (Eissenstat and Yanai 1997; Guo et al. 2008; Montagnoli et al. 2012a), our results show that beech roots born in spring and winter generally lived longer than roots born in summer and early fall. and soil water content (SWC). Data refer to the 2008 growing season. Root mass and length values, represented by a multiple colours legend, increase from blue (lower value) to red (higher value). (Color figure online)

Therefore, the fine-root system will consist of different aged fine-root pools (Joslin et al. 2006). Moreover, from methodological point of view, we showed that monthly collection of live fine-root samples might better represent the population of 'fast-turnover roots' and strongly reduce misestimating.

Very fine-root annual production was very close to its annual mean standing mass, which means that at the seasonal maximum, very fine-root mass and length double the values measured at the beginning of the growing season. During the first growth phase, very fine-root length increased by nearly $1,200 \mathrm{~m}$ at an average growth rate of $15 \mathrm{~m} \mathrm{~m}^{-2} \mathrm{~d}^{-1}$ (inferable from Fig. 2), for decreasing thereafter with a similar rate. Differently, dry mass and length of fine roots, during the same growth phase, increased only $50 \%$ of the initial value, with a root length growth rate of $2.3 \mathrm{~m} \mathrm{~m}^{-2} \mathrm{~d}^{-1}$ (inferable from Fig. 2). 
Many evidences (Gill and Jackson 2000; McCormack et al. 2012) show how fine-root lifespan is inversely related to diameter with decreasing turnover rates as root diameter increases. Therefore, very fine roots $(<0.5 \mathrm{~mm})$ may be clearly ascribed to the short-lived and fast-growing pool of the entire fine root system, whereas the fine roots $(0.5-2 \mathrm{~mm})$ to the long-lived portion. The highly probable mechanism underlying these different behaviours relies on differences among the primary and secondary growths. For very fine roots, the fast growth was driven by the longitudinal primary growth which allowed root elongation. For fine roots, the increase was 'apparently' longitudinal as it is mainly driven by the radial secondary growth, whose beginning depends on the timing of cambium formation along a root axis (Barlow 1997).

Fine-root biomass generally peaks in mid- to late summer and is minimal in late fall to early winter (Brassard et al. 2009 and references therein). It has been suggested that this seasonal variation may reflect that of SWC and, consequently, the nutrient availability (Coners and Leuschner 2005; Vanguelova et al. 2005; Mainiero and Kazda 2006), as well as an ontogenetic response to local conditions (Chiatante et al. 2005). In beech forests surveyed in the present work, the first peak of both very fine- and fineroot mass and length was observed when mean ST was 14-15 ${ }^{\circ} \mathrm{C}$ and SWC $44 \%$. Above this ST, with almost constant SWC (never below the field capacity), both fineroot traits decreased independently from the diameter class. In accordance with other studies (Pregitzer et al. 2000; Barney 1951; Merrit 1968; McMichael and Burke 1998), if soil moisture and nutrient availability are adequate, rates of root growth increase with increasing ST up to an optimum, 14-15 ${ }^{\circ} \mathrm{C}$ in our case, and then decline at supraoptimal temperatures. A second not significant increment was observed at the end of September, although it started from the end of August when ST decreased back to $14^{\circ} \mathrm{C}$ and SWC increased again to $46 \%$. This second increment is worth to note because it highlights that if adequate ST and water content are restored, a new flush of fine-root production is stimulated. Furthermore, we observed that the second increment was higher in the fine-root fraction than in the very fine-root one. In this regard, it is reasonable to state that beside the production of new roots for both fractions, the percentage of very fine roots that did not die after the first flush, continued their growth in radial pattern, shifting in the fine-root diameter class. Therefore, two switching points in root activity are detectable from the fine-root mass and length seasonal variation in both diameter classes, highlighting ST of $14-15^{\circ} \mathrm{C}$ as the optimal condition for root growth in $F$. sylvatica stand. Regression analyses revealed that SWC affected both root dry mass and length independently from the diameter class. In contrast, ST affected both mass and length only for very fine roots. For fine roots, ST missed this relationship because first and second peaks showed similar magnitude, and the latter was observed at markedly lower ST $\left(8{ }^{\circ} \mathrm{C}\right)$. Therefore, these findings pointed out that fine-root growth, mainly radial type, seems to be driven by SWC, whereas very fine-root growth, mainly longitudinal type, seems to be driven by ST.

The mechanism occurring when SWC decrease and temperature increase, as the carbon gain is lowered by the reduction in stomatal conductance, suggests that carbon is preferentially channelled into the fine-root production (Dickson and Tomlinson 1996; Thomas and Gausling 2000; Di Iorio et al. 2011). At the level of this component, $F$. sylvatica adopted an intensive strategy by increasing SRL, which increases the volume of soil exploited per unit biomass invested in fine roots (Ostonen et al. 2007; Montagnoli et al. 2012a; Comas et al. 2002; Curt and Prevosto 2003; Comas and Eissenstat 2004). In fact, SRL peaked when soil moisture content decreased to the lowest value of the growing season. For the significant second F SRL peak, the hypothesis here suggested is that if mortality and production of fine roots are concomitant processes (Kurz and Kimmins 1987; Hendrick and Pregitzer 1993) then the amount of new roots, usually high SRL type, is lower than that of dead roots. The lowest average mean diameter, whose contribution to SRL is inversely squared (Ostonen et al. 2007), measured for FR (data not shown) on 26 August clearly explains the significant SRL increase and the ongoing fine-root turnover process, supporting this hypothesis. Our findings supported also the tested hypothesis that the occurrence of polynomial relationship between a fine-root trait and two soil environmental variables enable the interpolation approach to delineate a round-shaped (2D view) physiological optimum as narrower as stronger the relationships. In particular, this was the case for very fine-root mass. Also very fine-root length showed a good interpolation, but in this case the weak relationship $(p=0.06)$ with SWC resulted in a wider elliptical range.

\section{Conclusions}

The present work on fine-root dynamics in southern European beech forest reveals a bimodal seasonal pattern with two increments corresponding to two different growth phases. The first peak, characterized by the higher increment, was observed in mid-summer while the second peak at the beginning of fall. The two fine-root diameter classes investigated showed that lifespan is inversely related to diameter, with decreasing turnover rates as root diameter increases. These differences in seasonal dynamics highlight different growth mechanisms such as radial type for fine 
roots mainly driven by SWC and longitudinal type for very fine roots mainly driven by ST. Moreover, $F$. sylvatica seems to adopt an intensive strategy by increasing SRL with decreasing SWC. Throughout the entire growing season, SWC never went below $34 \%$, making the ST within the $12-16{ }^{\circ} \mathrm{C}$ range the main stimulating factor for very fine-root growth. Further evidences indicate very fine roots as the most reasonable fine-root size in terms of responsiveness to soil environmental changes. The clear delineation of the physiological optimum for the very fineroot diameter class only gives further support to this assumption.

Acknowledgments We are grateful to Dr. Samanta Riva for her valuable help in the field and laboratory work, to Dr. Davide Beccarelli and Dr. Lorenzo Guerci from Consorzio Forestale 'Lario Intelvese' for helping with the field work and data on forest management. This work was supported in part by the Italian Ministry of Environment, Italian Ministry for University and Research (PRIN 2008), University of Insubria (FAR); EC FP7 Project ZEPHYR308313. The authors are also indebted to the Italian Botanic Society Onlus for supporting this research.

\section{References}

Barlow PW (1997) Stem cells and founder zones in plants, particularly their roots. In: Potten CS (ed) Stem cells. Academic Press, London, pp 29-57

Barlow PW (2010) Plastic, inquisitive roots and intelligent plants in the light of some new vistas in plant biology. Plant Biosyst 144:396-407

Barney CW (1951) Effects of soil temperature and light intensity on root growth of loblolly pine seedlings. Plant Physiol 26:146-163

Benjamin JG, Nielsen DC (2004) A method to separate plant roots from soil and analyze root surface area. Plant Soil 267:225-234

Bevington KB, Castle WS (1985) Annual Root Growth Pattern of Young Citrus Trees in Relation to Shoot Growth, Soil Temperature, and Soil Water Content. J Am Soc Hortic Sci 110:840-845

Bolte A, Villanueva I (2006) Interspecific competition impacts on the morphology an distribution of fine roots in European beech (Fagus sylvatica L.) and Norway spruce (Picea abies (L.) Karst.). Eur J For Res 125:15-26

Brassard BW, Chen H-YH, Bergeron Y (2009) Influence of Environmental Variability on Root Dynamics in Northern Forests. Crit Rev Plant Sci 28:179-197

Brunner I, Bakker MR, Björk RG, Hirano Y, Lukac M, Aranda X, Børja I, Eldhuset TD, Helmisaari HS, Jourdan C, Konôpka B, López BC, Miguel Pérez C, Persson H, Ostonen I (2013) Fineroot turnover rates of European forests revisited: an analysis of data from sequential coring and ingrowth cores. Plant Soil 362: 357-372

Burke MK, Raynal DJ (1994) Fine root growth phenology, production and turnover in a northern hardwood forest ecosystem. Plant Soil 162:135-146

Čermák J, Kučera J, Nadezhdina N (2004) Sap flow measurements with some thermodynamic methods, flow integration within trees and scaling up from sample trees to entire forest stands. Trees 18:529-546

Chiatante D, Di Iorio A, Scippa GS (2005) Root responses of Quercus ilex L. seedlings to drought and fire. Plant Biosyst 139:198-208
Comas LH, Eissenstat DM (2004) Linking root traits to maximum potential growth rate among eleven mature temperate tree species. Funct Ecol 18:388-397

Comas LH, Bouma TJ, Eissenstat DM (2002) Linking root traits to potential growth rate in six temperate tree species. Oecologia 132:34-43

Coners H, Leuschner C (2005) In situ measurement of fine root water absorption in three temperate tree species. - Temporal variability and control by soil and atmospheric factors. Basic Appl Ecol 6:395-405

Curt T, Prevosto B (2003) Rooting strategy of naturally regenerated beech in silver birch and Scots pine woodlands. Plant Soil 255:265-279

Di Iorio A, Montagnoli A, Scippa GS, Chiatante D (2011) Fine root growth of Quercus pubescens seedlings after drought stress and fire disturbance. Environ Exp Bot 74:272-279

Di Iorio A, Montagnoli A, Terzaghi M, Scippa GS, Chiatante D (2013) Effect of tree density on root distribution in Fagus sylvatica stands: a semi-automatic digitising device approach to trench wall method. Trees 27:1503-1513

Dickson RE, Tomlinson PT (1996) Oak growth, development and carbon metabolism in response to water stress. Ann Sci For 53:181-196

Edwards NT, Harris WF (1977) Carbon cycling in a mixed deciduous forest floor. Ecology 58:431-437

Eissenstat DM, Yanai RD (1997) The ecology of root lifespan. Adv Ecol Res 27:1-62

Finér L, Helmisaari HS, Lohmus K, Majdi H, Brunner I, Børja I, Eldhuset T, Godbold D, Grebenc T, Konopka B, Kraigher H, Mottonen M, Ohashi M, Oleksyn J, Ostonen I, Uri V, Vanguelova E (2007) Variation in fine root biomass of three European tree species: beech (Fagus sylvatica L.), Norway spruce (Picea abies L. Karst.), and Scots pine (Pinus sylvestris L.). Plant Biosyst 141:394-405

Finér L, Ohashib M, Noguchic K, Hirano Y (2011) Fine root production and turnover in forest ecosystems in relation to stand and environmental characteristics. For Ecol Manag 262:2008-2023

Fitter AH (1976) Effects of nutrient supply and competition from other species on root growth of Lolium perenne in soil. Plant Soil 45:177-189

Fitter AH (1985) Functional significance of root morphology and root system architecture. In: Fitter AH, Atkinson D, Read DJ, Usher MB (eds) Ecological interactions in soil. Blackwell Scientific, Oxford, pp 87-106

Fitter AH (1991) Characteristics and functions of root systems. In: Waisel Y, Eshel A, Kafkafi U (eds) Plant roots: the hidden half. Marcel Dekker, New York, pp 3-25

Gill AR, Jackson RB (2000) Global patterns of root turnover for terrestrial ecosystems. New Phytol 147:13-31

Godbold DL, Friz HW, Jentschke G, Meesenburg H, Rademacher P (2003) Root turnover and root necromass accumulation of Norway spruce (Picea abies) are affected by soil acidity. Tree Physiol 23:915-921

Guo D, Mitchell RJ, Withington JM, Fan P-P, Hendricks JJ (2008) Endogenous and exogenous controls of root life span, mortality and nitrogen flux in a longleaf pine forest: root branch order predominates. J Ecol 96:737-745

Helmisaari HS, Makkonen K, Kellomäki S, Valtonen E, Mälkönen E (2002) Below- and above-ground biomass, production and nitrogen use in Scots pine stands in eastern Finland. For Ecol Manag 165:317-326

Hendrick RL, Pregitzer KS (1992) Spatial variation in root distribution and growth associated with minirhizotrons. Plant Soil 143:283-288 
Hendrick RL, Pregitzer KS (1993) Patterns of fine root mortality in two sugar maple forests. Nature 361:59-61

Hendrick RL, Pregitzer KS (1996) Temporal and depth-related patterns of fine root dynamics in northern hardwood forests. J Ecol 87:167-176

Hertel D, Leuschner C (2002) A comparison of four different fine root production estimates with ecosystem carbon balance data in a Fagus-Quercus mixed forest. Plant Soil 239:237-251

IUSS Working Group WRB (2006) "World reference base for soil resources 2006" in World Soil Resources Reports 103 Rome. FAO. doi:10.1016/j.chemosphere.2004.06.007

Jackson RB, Mooney HA, Schulze ED (1997) A global budget for fine-root biomass, surface area, and nutrient contents. Proc Natl Acad Sci USA 94:7362-7366

Joslin JD, Wolfe MH, Hanson PJ (2001) Factors controlling the timing of root elongation intensity in a mature upland oak stand. Plant Soil 228:201-212

Joslin JD, Gaudinski JB, Torn MS, Riley WJ, Hanson PJ (2006) Fineroot turnover patterns and their relationship to root diameter and soil depth in a 14 C-labeled hardwood forest. New Phytol 172:523-535

Kaspar TC, Bland WL (1992) Soil temperature and root growth. Soil Sci 154:290-299

King JS, Pregitzer KS, Zak DR (1999) Clonal variation in above- and belowground growth responses of Populus tremuloides Michaux: influence of soil warming and nutrient availability. Plant Soil 217:119-130

Kuhns MR, Garrett HE, Teskey RO, Hinckley TM (1985) Root growth of black walnut trees related to soil temperature, soil water potential, and leaf water potential. For Sci 31:617-630

Kurz WA, Kimmins JP (1987) Analysis of some sources of error in methods used to determine fine root production in forest ecosystems: a simulation approach. Can J For Res 17:909-912

Larson MM (1970) Root regeneration and early growth of red oak seedlings: influence of soil temperature. For sci 16:442-446

Lieffers VJ, Rothwell RL (1986) Effects of depth of water table and substrate temperature on root and top growth of Picea mariana and Larix laricina seedlings. Can J For Res 16:1201-1206

Lyr H (1996) Effect of the root temperature on growth parameters of various European tree species. Ann Sci For 3:317-323

Lyr H, Garbe V (1995) Influence of root temperature on growth of Pinus sylvestris, Fagus sylvatica and Quercus robur. Trees 9:220-223

Lyr H, Hoffmann G (1967) Growth rates and growth periodicity of tree roots. Int Rev For Res 2:181-236

Mainiero R, Kazda M (2006) Depth-related fine root dynamics of Fagus sylvatica during exceptional drought. For Ecol Manag 237:135-142

Majdi K, Pregitzer KS, Moren AS, Nylund JE, Agren GI (2005) Measuring fine-root turnover in forest ecosystems. Plant Soil 276:1-8

Manes F, Vitale M, Donato E, Giannini M, Puppi G (2006) Different ability of three Mediterranean oak species to tolerate progressive water stress. Photosynthetica 44:387-393

McClaugherty CA, Aber JD, Melillo JM (1982) The role of fine roots in the organic matter and nitrogen budgets of two forested ecosystems. Ecology 63:1481-1490

McCormack ML, Adams TS, Smithwick EAH, Eissenstat DM (2012) Predicting fine root lifespan from plant functional traits in temperate trees. New Phytol 95:823-831

McMichael BL, Burke JJ (1998) Soil Temperature and Root Growth. Hortic Sci 33:947-951

Merrit C (1968) Effect of environment and heredity on the rootgrowth pattern of red pine. Ecology 49:34-40

Metcalfe D, Meir P, Aragão LEOC, da Costa ACL, Braga AP, Gonçalves PHL, de Athaydes Silva J Jr, de Almeida SS, Dawson
LA, Malhi Y, Williams M (2008) The effects of water availability on root growth and morphology in an Amazon rainforest. Plant Soil 311:189-199

Montagnoli A, Di Iorio A, Ceriani RM, Scippa GS, Chiatante D (2010) Root seasonal pattern, spatial distribution, and C: $\mathrm{n}$ ratio of matgrass pasture (Nardus stricta L.) in the Lombardy Prealps. Plant Biosyst 144:463-470

Montagnoli A, Terzaghi M, Di Iorio A, Scippa GS, Chiatante D (2012a) Fine-root morphological and growth traits in a Turkeyoak stand in relation to seasonal changes in soil moisture in the Southern Apennines, Italy. Ecol Res 27:1015-1025

Montagnoli A, Terzaghi M, Di Iorio A, Scippa GS, Chiatante D (2012b) Fine-root seasonal pattern, production and turnover rate of European beech (Fagus sylvatica L.) stands in Italy Prealps: possible implications of coppice conversion to high forest. Plant Biosyst 146:1012-1022

Ostonen I, Puttsepp U, Biel C, Alberton O, Bakker MR, Lohmus K, Majdi H, Metcalfe D, Olsthoorn AFM, Pronk A, Vanguelova E, Weih M, Brunner I (2007) Specific root length as an indicator of environmental change. Plant Biosyst 141:426-442

Ostonen I, Helmisaari H-S, Borken W, Tedersoo L, Kukumagi M, Bahram M, Lindroos AJ, No jd P, Uri V, Merila P, Asi E, Lõhmus K (2011) Fine root foraging strategies in Norway spruce forests across a European climate gradient. Glob Change Biol 17:3620-3632

Piovesan G, Biondi F, Bernabei M, Di Filippo A, Schirone B (2005) Spatial and altitudinal bioclimatic zones of the Italian peninsula identified from a beech (Fagus sylvatica L.) tree-ring network. Acta Oecologica 27:197-210

Ponder Jr F, Alley DE. 1997. Soil sampler for rocky soils. Res Note NC-371 USDA Forest Service North Central Forest Experiment Station, St. Paul, MN. p 5

Pregitzer KS, King JS, Burton AJ, Brown SE (2000) Responses of tree roots to temperature. New Phytol 147:105-115

Steele SJ, Gower ST, Vogel JG, Norman JM (1997) Root mass, net primary production and turnover in aspen, jack pine, and black spruce forests in Saskatchewan and Manitoba, Canada. Tree Physiol 17:577-587

Terzaghi M, Montagnoli A, Di Iorio A, Scippa GS, Chiatante D (2013) Fine-root carbon and nitrogen concentration of European beech (Fagus sylvatica L.) in Italy Prealps: possible implications of coppice conversion to high forest. Frontiers in Plant Science doi: $10.3389 /$ fpls.2013.00192

Teskey RO, Hinckley TM (1981) Influence of temperature and water potential on root growth of white oak. Physiol Plant 52:363-369

Thomas FM, Gausling T (2000) Morphological and physiological responses of oak seedlings (Quercus petraea and Q. robur) to moderate drought. Ann For Sci 57:325-333

Tierney GL, Fahey TJ, Groffman PM, Hardy JP, Fitzhugh RD, Driscoll CT, Yavitt JB (2003) Environmental control of fine root dynamics in a northern hardwood forest. Glob Change Biol 9:670-679

Tryon PR, Chapin FS (1983) Temperature control over root growth and root biomass in taiga forest trees. Can J For Res 13:827-833

Vanguelova EI, Nortcliff S, Moffat AJ, Kennedy F (2005) Morphology, biomass and nutrient status of fine roots of Scots pine (Pinus sylvestris) as influenced by seasonal fluctuations in soil moisture and soil solution chemistry. Plant Soil 270:233-247

Vogt KA, Persson H (1991) Root methods. In: Lassoie JP, Hinckley TM (eds) Techniques and Approaches in Forest Tree Ecophysiology. CRC Press Boca Raton, Florida USA, pp 477-502

Vogt KA, Vogt DJ, Palmiotto PA, Boon P, O'Hara J, Asbjornsen H (1996) Review of root dynamics in forest ecosystems grouped by climate, climatic forest type and species. Plant Soil 187:159-219

Vogt KA, Vogt DJ, Bloomfield J (1998) Analysis of some direct and indirect methods for estimating root biomass and production of forest at an ecosystem level. Plant Soil 200:71-89 
Wells CE, Eissenstat DM (2001) Marked differences in survivorship among apple roots of different diameters. Ecology 82:882-892

Weltzin JF, Pastor J, Harth C, Bridgham SD, Updegraff K, Chapin CT (2000) Response of bog and fen plant communities to warming and water table manipulations. Ecology 81:3464-3478

Wilcox H-E, Ganmore-Neumann R (1975) Effects of Temperature on Root Morphology and ectendomycorrhizal development in Pinus resinosa Ait. Can J For Res 5:171-175
Withington JM, Reich PB, Oleksyn J, Eissenstat DM (2006) Comparisons of structure and life span in roots and leaves among temperate trees. Ecol Monogr 76:381-397

Zobel RW, Waisel Y (2010) A plant root system architectural taxonomy: a framework for root nomenclature. Plant Biosyst 144:507-512 